\title{
PENGARUH PERPUTARAN MODAL KERJA, UKURAN PERUSAHAAN DAN LIKUIDITAS TERHADAP PROFITABILITAS PERUSAHAAN TEKSTIL DAN GARMEN
}

\author{
Ni Luh Komang Arik Santini ${ }^{1}$ \\ I Gde Kajeng Baskara
}

${ }^{1,2}$ Fakultas Ekonomi dan Bisnis Universitas Udayana (Unud), Bali, Indonesia

E-mail: ariksantini@yahoo.com

\begin{abstract}
ABSTRAK
Tujuan penelitian ini adalah untuk mengetahui pengaruh perputaran modal kerja, ukuran perusahaan dan likuiditas terhadap profitabilitas perusahaan tekstil dan garmen. Penelitian dilakukan di Bursa Efek Indonesia tahun 2014-2016. Jumlah sampel yang digunakan 8 perusahaan dengan menggunakan metode purposive sampling. Teknik analisis yang digunakan adalah regresi linier berganda. Sebelum dilakukan analisis regresi linier berganda, terlebih dahulu dilakukan uji asumsi klasik untuk memastikan model regresi linear yang digunakan telah memenuhi asumsi dasar dari analisis regresi linear berganda. Hasil penelitian menunjukkan bahwa perputaran modal kerja berpengaruh positif dan signifikan terhadap profitabilitas, ukuran perusahaan tidak berpengaruh signifikan terhadap profitabilitas dan likuiditas berpengaruh positif dan signifikan terhadap profitabilitas.
\end{abstract}

Kata kunci: profitabilitas, perputaran modal kerja, ukuran perusahaan, likuiditas

\begin{abstract}
The purpose of this study was to determine the effect of working capital turnover, company size and liquidity on the profitability of textile and garment companies. The research is conducted in Indonesia Stock Exchange year 2014-2016. The number of samples used by 8 companies using purposive sampling method. The analysis technique used is multiple linear regression. Before the multiple linear regression analysis was carried out, the classical assumption test was performed to ensure that the linear regression model used had met the basic assumptions of multiple linear regression analysis. The results showed that working capital turnover had a positive and significant effect on profitability, the size of the company had no significant effect on profitability and liquidity had a positive and significant effect on profitability.
\end{abstract}

Keywords: profitability, working capital turnover, firm size, liquidity 


\section{PENDAHULUAN}

Setiap perusahaan pada dasarnya tidak terlepas dari tujuannya yaitu untuk memperoleh laba yang optimal untuk kelangsungan hidup perusahaannya. Kelangsungan hidup perusahaan dipengaruhi oleh banyak hal antara lain profitabilitas perusahaan itu sendiri (Sartono, 2010:122). Profitabilitas adalah kemampuan suatu perusahaan untuk mencapai dan meningkatkan laba atau keuntungan yang didapatkan, dengan bahasa lain profitabilitas merupakan suatu ukuran yang menunjukkan perbandingan antara laba dengan aktiva atau modal yang digunakan menghasilkan laba perusahaan (Sartono, 2010:122). Profitabilitas perusahaan merupakan salah satu dasar penilaian kondisi suatu perusahaan, untuk itu dibutuhkan suatu alat analisis untuk dapat menilainya. Alat analisis yang dimaksud adalah rasio-rasio keuangan. Dalam mengukur profitabilitas ini rasio keuangan yang digunakan adalah rasio profitabilitas.

Rasio profitabilitas digunakan untuk mengukur efektivitas manajemen berdasarkan hasil pengembalian yang diperoleh dari penjualan dan investasi. Menurut Sartono (2010:123) ada beberapa pengukuran rasio profitabilitas, antara lain: Gross Profit Margin (GPM), Net Profit Margin (NPM), Return On Assets (ROA) dan Return On Equity (ROE). Profitabilitas dalam penelitian ini diukur dengan menggunakan Return On Assets (ROA). Dengan mengetahui rasio ini, akan dapat diketahui apakah perusahaan efisien dalam memanfaatkan aktivanya dalam kegiatan operasional perusahaan. Rasio ini juga memberikan ukuran yang lebih baik atas profitabilitas perusahaan karena menunjukkan efektifitas dalam menggunakan aktiva untuk memperoleh pendapatan. 
Profitabilitas perusahaan dipengaruhi oleh dua faktor yaitu faktor internal dan faktor eksternal perusahaan. Menurut Soebiantoro (2007) faktor internal adalah merupakan sekumpulan variabel yang dapat dikendalikan perusahaan sedangkan faktor eksternal tidak dapat dikendalikan secara langsung oleh perusahaan. Faktor eksternal perusahaan adalah faktor yang dapat mempengaruhi profitabilitas perusahaan dari luar perusahaan itu sendiri misalnya kondisi makro ekonomi. Lingkungan ekonomi makro akan mempengaruhi operasional perusahaan yang dalam hal ini keputusan pengambilan kebijakan yang berkaitan dengan kinerja keuangan perbankan, seperti inflasi, suku bunga dan produk domestik bruto (PDB). Menurut Kasmir (2013:89) faktor-faktor yang dapat mempengaruhi profitabilitas yaitu margin laba bersih, perputaran total aktiva, laba bersih, penjualan, total aktiva, aktiva tetap, aktiva lancar, dan total biaya.

Menurut Tandelilin (2010:372), salah satu indikator untuk melihat prospek suatu perusahaan dimasa datang adalah dengan melihat pertumbuhan profitabilitas perusahaan. Semakin tinggi profitabilitas suatu perusahaan maka semakin berpeluang perusahaan tersebut akan berkembang dimasa mendatang mengingat keuntungan yang diperoleh dapat diinvestasikan kembali untuk operasional perusahaan. Sebaliknya apabila profitabilitas perusahaan rendah maka peluang untuk berkembang semakin kecil. Profitabilitas yang tinggi akan mendukung kegiatan operasional secara maksilmal. Dalam penelitian ini profitabilitas dipengaruhi oleh perputaran modal kerja, ukuran perusahaan dan likuiditas. Apabila perusahaan tidak dapat mempertahankan "tingkat perputaran modal kerja yang baik", maka kemungkinan sekali perusahaan akan berada dalam keadaan 
insolvent (tidak mampu membayar kewajiban-kewajiban yang sudah jatuh tempo) dan bahkan mungkin terpaksa harus dilikuidasi atau bangkrut (Lukman Syamsudin, 2007:201).

Menurut Sawir (2009:129) Modal kerja adalah keseluruhan aktiva lancar yang dimiliki oleh perusahaan atau dapat pula dimaksudkan sebagai dana yang harus tersedia untuk membiayai kegiatan operasi perusahaan sehari-hari. Pengelolaan modal kerja dapat dilihat dari perputaran modal kerja atau working capital turnover yang merupakan salah satu rasio untuk mengukur atau menilai keefektifan modal kerja perusahaan selama periode tertentu yang artinya seberapa banyak modal kerja berputar selama satu periode atau dalam suatu periode. Rasio ini diukur dengan cara membandingkan antara penjualan dengan total aktiva lancar dikurangi hutang lancar (Kasmir, 2012: 182). Modal kerja merupakan bagian yang penting bagi perusahaan untuk kegiatan operasionalnya sehari-hari. Selain itu, informasi modal kerja digunakan untuk mengambil keputusan mengenai jumlah dan komposisi aktiva lancar dan bagaimana membiayai aktiva.

Munawir (2004:240) menyatakan bahwa perputaran modal kerja menunjukkan berapa kali dana yang tertanam dalam modal kerja dan berputar dalam satu periode. Jumlah penjualan yang bisa dicapai oleh setiap rupiah modal kerja, dan jumlah penjualan tersebut otomatis berpengaruh terhadap profitabilitas. Semakin cepat perputaran modal kerja menunjukkan semakin efektif penggunaan modal kerja yang berdampak pada meningkatnya profitabilitas perusahaan. Dengan adanya perputaran modal kerja yang tinggi perusahaan tidak akan mengalami kesulitan dan hambatan yang akan mungkin timbul di masa yang akan 
datang yang akan berdampak pada perolehan profit perusahaan. Berdasarkan penelitian sebelumnya perputaran modal kerja diketahui berpengaruh positif dan signifikan terhadap profitabilitas perusahaan sebagaimana diungkapkan oleh Adjapong and Padachi (2014), Geetam and Samanta (2017), Tsagem et al. (2015) serta Dharmendra (2015) sedangkan menurut Zeeshan Ahmed et al. (2016) mengungkapkan bahwa perputaran modal kerja berpengaruh negatif terhadap profitabilitas perusahaan.

Faktor kedua dari penelitian ini adalah ukuran perusahaan yang menggambarkan besar kecilnya suatu perusahaan dimana perusahaan yang besar akan lebih mudah mendapatkan pinjaman dari luar baik dalam bentuk hutang maupun modal saham karena biasanya perusahaan besar disertai dengan reputasi yang cukup baik dimata masyarakat (Sartono, 2010:249). Penentuan besar kecilnya ukuran perusahaan dapat ditentukan berdasarkan total penjualan, total aktiva, rata-rata tingkat penjualan, dan rata-rata total aktiva (Seftianne dan Handayani, 2011).

Sawir (2005:101) menyatakan bahwa ukuran perusahaan dinyatakan sebagai determinan dari struktur keuangan. Ukuran perusahaan adalah suatu skala atau nilai dimana perusahaan dapat diklasifikasikan besar kecilnya berdasarkan total aktiva, log size, nilai saham, dan lain sebagainya. Pada dasarnya ukuran perusahaan hanya terbagi dalam tiga kategori yaitu perusahaan besar (large firm), perusahaan menengah (medium-size) dan perusahaan kecil (small firm). Salah satu tolak ukur yang menunjukkan besar kecilnya perusahaan adalah total aset atau aktiva dari perusahaan tersebut. Perusahaan yang memiliki total aset besar 
menunjukkan bahwa perusahaan tersebut telah mencapai tahap kedewasaan dimana dalam tahap ini arus kas perusahaan sudah positif dan dianggap memiliki prospek yang baik dalam jangka waktu yang relatif lama. Selain itu aset perusahaan yang besar akan membuat perusahaan lebih stabil dibandingkan perusahaan kecil, karena memiliki kontrol yang lebih baik terhadap kondisi pasar, kurang rentan terhadap fluktuasi ekonomi, sehingga mampu menghadapi persaingan ekonomi. Berdasarkan penelitian sebelumnya yang dilakukan oleh Yazdanfar and Ohman (2016) mengungkapkan bahwa ukuran perusahaan berpengaruh positif terhadap profitabilitas perusahaan, hal ini juga didukung oleh peneliti sebelumnya yaitu Yazdanfar and Ohman (2014), Ehi-Oshio et al. (2013), Gill et al. (2011), Abu Tapanjeh (2016), Yazdanfar Darush (2013) serta Niresh and Velnampy (2014).

Menurut Kasmir (2010:128) likuiditas adalah ketidakmampuan perusahaan membayar kewajibannya terutama utang jangka pendek yang sudah jatuh tempo yang disebabkan oleh berbagai faktor. Pertama, bisa dikarenakan memang perusahaan sedang tidak memiliki dana sama sekali. Kedua, bisa saja perusahaan memiliki dana namun pada saat jatuh tempo tidak memiliki dana sama sekali secara tunai sehingga harus menunggu dalam waktu tertentu, untuk mencairkan aktiva lainnya seperti menagih hutang, menjual surat-surat berharga, atau menjual aktiva lainnya yang dimiliki perusahaan.

Likuiditas yang diproksikan dengan current ratio $(C R)$ adalah salah satu rasio yang mengukur tingkat likuiditas perusahaan dengan cara membandingkan aset lancar dengan hutang lancar. Menurut Brigham (2012:134) current ratio 
merupakan sebuah rasio likuiditas yang menggambarkan sampai sejauh apa kewajiban lancar ditutupi oleh aset yang diharapkan akan dikonversikan menjadi kas dalam waktu dekat. Investor dapat menggunakan rasio ini untuk mengukur kemampuan perusahaan dalam menutup hutang lancarnya dengan aset lancar yang dimiliki. Menurut Sartono (2011:206), semakin tinggi current ratio berarti semakin besar kemampuan perusahaan untuk memenuhi kewajiban jangka pendek. Current ratio yang terlalu tinggi menunjukkan kelebihan aktiva lancar yang menganggur. Jadi hal tersebut tidak baik bagi profitabilitas perusahaan karena aktiva lancar menghasilkan return yang lebih rendah dibandingkan dengan aktiva tetap (Hanafi dan Halim, 2003:54). Berdasarkan peneliti terdahulu yang dilakukan oleh Khatik and Varyhese (2015) menyatakan bahwa likuiditas berpengaruh positif terhadap profitabilitas tetapi hal ini tidak sejalan dengan penelitian yang dilakukan oleh Ehi-Oshio et al. (2013), Gill et al. (2011), serta Varghesa and Dhote (2014) menyatakan bahwa likuiditas berdampak negatif terhadap profitabilitas.

Penelitian ini dilakukan pada industri tekstil dan garmen mengingat perkembangan industri tekstil dan garment di Indonesia menarik untuk dicermati. Industri tekstil dan garmen saat ini menjadi industri strategis bagi perekonomian Indonesia mengingat Indonesia memiliki 250 juta penduduk. Bahkan, industri ini bagian sektor manufaktur terbesar ketiga di Indonesia dan menjadi salah satu sektor yang paling banyak menyerap tenaga kerja. Ekspor tekstil dan produk tekstil Indonesia mencapai US\$12,4 miliar pada tahun 2017, melebihi target dari Asosiasi Pertekstilan Indonesia (API) sebesar US $\$ 11,8$ miliar. Pemerintah sendiri 
bahkan menargetkan pertumbuhan ekspor di 2019 tumbuh menjadi US\$15 miliar. Permintaan tekstil yang tinggi di Asia Tenggara dan Timur Tengah menjadi faktor yang menentukan untuk mencapai target tersebut (www.tribun.com). Hal inilah yang menjadi alasan peneliti memilih perusahaan tekstil dan garmen sebagai sampel penelitian karena industri ini merupakan salah satu industri yang terus mengalami perkembangan disetiap tahunnya.

Menurut Samsul (2006:200) terdapat berbagai faktor yang mempengaruhi kinerja keuangan perusahaan baik itu faktor mikro maupun faktor makro. Faktor makro ekonomi adalah faktor-faktor yang mempengaruhi ekonomi yang merupakan faktor eksternal yang mempunyai pengaruh terhadap kinerja saham maupun perusahaan baik secara langsung maupun tidak langsung, seperti tingkat bunga, tingkat inflasi, kurs valuta asing, peredaran uang, kebijakan pemerintah dan lain-lain, sedangkan faktor mikro ekonomi berada dalam perusahaan itu sendiri antara lain ditunjukkan oleh rasio keuangan perusahaan, seperti margin laba bersih, perputaran total aktiva, laba bersih per saham (Earning per Share/EPS), penjualan, total aktiva, aktiva tetap, aktiva lancar, total biaya, nilai buku persaham, rasio ekuitas terhadap utang (debt to equity ratio), dan lain-lain. Penilaian kinerja perusahaan dengan memperhatikan faktor makro sangat penting dilakukan, untuk mengetahui pengaruh yang mungkin timbul dari faktor eksternal yang tidak dapat diatur oleh perusahaan itu sendiri yang nantinya dapat mempengaruhi kinerja perusahaan.

Profitabilitas adalah kemampuan suatu perusahaan untuk mencapai dan meningkatkan laba atau keuntungan yang didapatkan, dengan bahasa lain 
profitabilitas merupakan suatu ukuran yang menunjukkan perbandingan antara laba dengan aktiva atau modal yang digunakan menghasilkan laba perusahaan (Sartono, 2010:122). Menurut Putra (2012) profitabilitas menggambarkan kemampuan perusahaan mendapatkan laba melalui semua kekayaan dan sumber yang ada, seperti kegiatan penjualan, kas, modal, jumlah karyawan, jumlah cabang dan sebagainya. Jumlah laba bersih kerap dibandingkan dengan ukuran kegiatan atau kondisi keuangan lainnya seperti penjualan, aktiva, ekuitas pemegang saham untuk menilai kinerja sebagai suatu persentase dari beberapa tingkat aktivitas atau investasi. Perbandingan ini disebut rasio profitabilitas (profitability ratio). Menurut Raharjaputra (2009:199) rasio profitabilitas merupakan rasio yang mengukur seberapa besar efektivitas manajemen atau eksekutif perusahaan yang dibuktikan dengan kemampuan menciptakan keuntungan atau dapat diartikan mampu menciptakan nilai tambah ekonomis perusahaan.

Rasio profitabilitas mengukur efektivitas manajemen berdasarkan hasil pengembalian yang diperoleh dari penjualan dan investasi. Profitabilitas juga mempunyai arti penting dalam usaha mempertahankan kelangsungan hidup perusahaan dalam jangka panjang, karena profitabilitas menunjukkan apakah badan usaha tersebut mempunyai prospek yang baik di masa yang akan datang. Dengan demikian, setiap badan usaha akan selalu berusaha meningkatkan profitabilitasnya, karena semakin tinggi tingkat profitabilitas suatu badan usaha, makan kelangsungan hidup badan usaha tersebut akan lebih terjamin. 
Faktor yang mempengaruhi profitabilitas perusahaan Menurut Soebiantoro (2007) terdapat dua faktor. Faktor internal adalah merupakan sekumpulan variabel yang dapat dikendalikan perusahaan seperti penghimpunan dana, manajemen likuiditas serta rasio-rasio keuangan, rasio keuangan yang digunakan untuk mempengaruhi profitabilitas dalam penelitian ini adalah perputaran modal kerja, ukuran perusahaan dan likuiditas. Faktor eksternal merupakanperistiwa-peristiwa yang terjadi di luar perusahaan, sehingga tidak dapat dikendalikan secara langsung oleh perusahaan. Lingkungan ekonomi makro akan mempengaruhi operasional perusahaan yang dalam hal ini keputusan pengambilan kebijakan yang berkaitan dengan kinerja keuangan perbankan, seperti inflasi, suku bunga dan PDB (Produk Domestik Bruto).

Modal kerja adalah keseluruhan aktiva lancar yang dimiliki perusahaan atau dapat pula dimaksudkan sebagai dana yang harus tersedia untuk membiayai kegiatan operasi perusahaan sehari-hari (Sawir, 2009:129). Modal kerja sangat dibutuhkan dalam menjalankan kegiatan suatu perusahaan, modal kerja sangat penting dalam menunjang kelancaran kegiatan operasi perusahaan agar perusahaan dapat berjalan dengan baik secara berkesinambungan sehingga modal kerja harus tersedia, untuk membiayai berbagai pengeluaran perusahaan seharihari.

Menurut Munawir (2012:114) modal kerja penting bagi perusahaan karena dengan modal kerja yang cukup memungkinkan bagi perusahaan untuk beroperasi dengan seekonomis mungkin dan perusahaan tidak mengalami kesulitan atau menghadapi bahaya-bahaya yang mungkin timbul karena adanya krisis atau 
kekacauan keuangan. Akan tetapi adanya modal kerja yang berlebihan menunjukkan dana yang tidak produktif, dan hal ini akan menimbulkan kerugian bagi perusahaan karena adanya kesempatan untuk memperoleh keuntungan telah disia-siakan. Sebaliknya tidak tercukupinya modal kerja merupakan sebab utama kegagalan bagi perusahaan.

Menurut Kasmir (2012:182) perputaran modal kerja (net working capital turnover) adalah salah satu rasio yang digunakan untuk mengukur atau menilai kefektifan modal kerja perusahaan selama periode tertentu. Dalam pengelolaan modal kerja yang perlu diperhatikan tiga elemen utama modal kerja, yaitu kas, piutang dan persediaan. Dari semua elemen modal kerja dihitung perputarannya. Semakin cepat tingkat perputaran masing-masing elemen modal kerja, maka modal kerja dapat dikatakan efisien. Tetapi jika perputarannya semakin lambat, maka penggunaan modal kerja dalam perusahaan kurang efisien (Esra dan Apriweni, 2005). Untuk menilai efisiensi modal kerja dapat digunakan rasio antara total penjualan dengan jumlah modal kerja rata-rata yang sering disebut working capital turnover (perputaran modal kerja). Rasio ini menunjukkan hubungan antara modal kerja dengan penjualan yang dapat diperoleh perusahaan untuk tiap rupiah modal kerja. Perputaran modal kerja yang rendah menunjukkan adanya kelebihan modal kerja yang mungkin disebabkan rendahnya perputaran persediaan, piutang atau adanya saldo kas yang terlalu besar.

Ukuran perusahaan merupakan cerminan total aset perusahaan yang digunakan untuk menjalankan operasi perusahaan. Semakin besar ukuran perusahaan, berarti aset yang dimiliki perusahaan pun semakin besar dan dana 
yang dibutuhkan perusahaan untuk mempertahankan kegiatan operasionalnya pun semakin banyak. Semakin besar ukuran perusahaan akan mempengaruhi keputusan manajemen dalam memutuskan pendanaan apa yang akan digunakan oleh perusahaan agar keputusan pendanaan dapat mengoptimalkan nilai perusahaan.

Menurut Riyanto (2011:299) suatu perusahaan yang besar dimana sahamnya tersebar sangat luas, modal saham hanya akan mempunyai pengaruh yang kecil terhadap kemungkinan hilangnya atau tergesernya kontrol dari pihak dominan terhadap perusahaan yang bersangkutan. Sebaliknya perusahaan yang kecil sahamnya hanya tersebar di lingkungan kecil, penambahan jumlah saham akan mempunyai pengaruh yang besar terhadap kemungkinan hilangnya kontrol pihak dominan terhadap perusahaan yang bersangkutan. Dengan demikian maka pada perusahaan yang besar dimana sahamnya tersebar sangat luas akan lebih berani mengeluarkan saham baru dalam memenuhi kebutuhannya untuk membiayai pertumbuhan penjualan dibandingkan dengan perusahaan yang kecil.

Tingkat kepercayaan investor juga dapat diukur melalui ukuran perusahaan. Dimana semakin besar perusahaan, maka semakin dikenal oleh masyarakat yang artinya semakin mudah untuk mendapatkan informasi yang akan meningkatkan nilai perusahaan. Bagi perusahaan besar yang memiliki total aktiva yang tinggi akan membuat investor tertarik untuk menanamkan modalnya pada perusahaan tersebut. Ukuran perusahaan juga dapat diukur dengan menggunakan logaritma natural dari total aset perusahaan. (Ramadan, 2012). 
Menurut Sartono (2010:116) likuiditas menunjukan kemampuan untuk membayar kewajiban finansial jangka pendek tepat pada waktunya, likuiditas perusahaan ditunjukan oleh besar kecilnya aktiva lancar yaitu yang mudah untuk di ubah menjadi kas yang meliputi kas, surat berharga, piutang dan persediaan. Menurut Riyanto (2010:25-26) likuiditas berhubungan dengan masalah kemampuan suatu perusahaan untuk memenuhi kewajiban finansialnya yang segera harus di penuhi. Jumlah alat-alat pembayaran (alat-alat likuid) yang dimiliki oleh perusahaan pada suatu waktu tertentu merupakan kekuatan membayar dari perusahaan yang bersangkutan. Likuiditas perusahaan yang digunakan dalam penelitian ini adalah Current Ratio (CR) sebagai alat untuk menganalisis dan menilai posisi likuiditas perusahaan. Menurut Riyanto, (2010:28) current ratio adalah perbandingan antara aktiva lancar dengan utang lancar, maka setiap transaksi yang mengakibatkan perubahan jumlah aktiva lancar atau utang lancar baik masing-masing atau kedua-duanya, akan dapat mengakibatkan perubahan current ratio, yang ini berarti akan mengakibatkan perubahan tingkat likuiditas. Current ratio yang tinggi menunjukkan posisi yang baik bagi para kreditor, oleh karena terdapat kemungkinan yang lebih besar bahwa utang perusahaan itu akan dapat dibayar pada waktunya. Hal ini terutama berlaku bila pimpinan perusahaan menguasai pos-pos modal kerja dengan ketat dan semestinya. Pada umumnya suatu current ratio yang rendah lebih banyak mengandung risiko dari pada suatu current ratio yang tinggi, tetapi kadangkadang suatu current ratio yang rendah menunjukan pimpinan perusahaan menggunakan aktiva lancar sangat efektif yaitu bila saldo disesuaikan dengan 
kebutuhan minimum saja dan perputaran piutang dari persediaan ditingkatkan sampai pada tingkat maksimum. Jumlah kas yang diperlukan tergantung dari besarnya perusahaan dan terutama dari jumlah uang yang diperlukan untuk membayar utang lancar, berbagai biaya rutin dan pengeluaran darurat (Tunggal, 2005:157).

Menurut Munawir (2005:72) rasio yang paling umum digunakan untuk menganalisis posisi modal kerja suatu perusahaan adalah current ratio yaitu perbandingan antara jumlah aktiva lancar dengan hutang lancar. Rasio ini menunjukan bahwa nilai kekayaan lancar yang segera dapat dijadikan uang ada sekian kalinya hutang jangka pendek. Current ratio 200 persen kadang-kadang sudah memuaskan bagi suatu perusahaan, tetapi jumlah modal kerja dan besarnya rasio tergantung pada beberapa faktor, suatu standar atau rasio yang umum tidak dapat ditentukan untuk seluruh perusahaan. Current ratio 200 persen hanya merupakan kebiasaan (rule of thumb) dan akan digunakan sebagai titik tolak untuk mengadakan penelitian atau analisa yang lebih lanjut. Menurut Munawir (2004:72) current ratio ini menunjukkan tingkat keamanan (margin of savety) kreditor jangka pendek atau kemampuan perusahaan untuk membayar hutanghutang tersebut. Tetapi suatu perusahaan dengan current ratio yang tinggi belum tentu menjamin akan dapat dibayarnya hutang perusahaan yang sudah jatuh tempo karena proporsi atau distribusi dari aktiva lancar yang tidak menguntungkan, misalnya jumlah persediaan yang relatif tinggi dibandingkan taksiran tingkat penjualan yang akan datang sehingga tingkat perputaran persediaan rendah dan 
menunjukan adanya over investment dalam persediaan tersebut atau adanya saldo piutang yang besar yang mungkin sulit untuk ditagih.

Modal kerja adalah salah satu hal yang sangat penting bagi perusahaan karena perusahaan selalu membutuhkan modal kerja agar dapat membiayai kegiatan perusahaannya sehari-hari, misalnya untuk membeli persediaan barang dagangan, membayar upah buruh, gaji karyawan, dan sebagainya, dimana dana yang sudah dikeluarkan diharapkan bisa cepat kembali lagi masuk kedalam kas perusahaan melalui hasil penjualannya. Adanya modal kerja yang berlebihan menujukkan adanya dana yang tidak produktif dan hal ini memberikan kerugian karena dana yang tersedia tidak digunakan untuk kegiatan perusahaan. Sebaliknya, kekurangan modal kerja merupakan sebab utama kegagalan perusahaan dalan menjalankan perusahaannya. Keefektifan penggunaan modal kerja dapat diukur dengan rasio perputaran modal kerja (working capital turnover).

Modal kerja yang baik dan cukup akan menunjang tingginya profitabilitas perusahaan, semakin tinggi tingkat perputaran modal kerja semakin efektif penggunaan modal kerja dan semakin cepat modal kerja berputar sehingga semakin besar keuntungan yang didapatkan untuk meningkatkan profitabilitas perusahaan. Sehingga, modal kerja berpengaruh terhadap profitabilitas. Pernyataan tersebut didukung oleh penelitian Adjapong and Padachi (2014), Geetam and Samanta (2017), Tsagem et al. (2015) serta Dharmendra (2015) yang menunjukkan bahwa perputaran modal kerja berpengaruh positif signifikan terhadap profitabilitas perusahaan. 
$\mathrm{H}_{1}$ : Perputaran modal kerja berpengaruh positif dan signifikan terhadap profitabilitas.

Ukuran perusahaan menggambarkan besar kecilnya suatu perusahaan. Penentuan besar kecilnya skala perusahaan dapat ditentukan berdasarkan total penjualan, rata-rata tingkat penjualan, total aktiva dan rata-rata total aktiva. Perusahaan yang besar memiliki total asset yang besar, sehingga perusahaan mampu mengoptimalkan kineja perusahaan, dengan aset yang dimilikinya. Oleh sebab itu ukuran perusahaan merupakan salah satu faktor yang menentukan kemampuan perusahaan menghasilkan laba. Pernyataan tersebut didukung oleh penelitian Yazdanfar and Ohman (2014), Ehi-Oshio et al. (2013), Gill et al. (2011), Abu Tapanjeh (2016), Yazdanfar Darush (2013) serta Niresh and Velnampy (2014) yang menunjukkan bahwa ukuran perusahaan berpengaruh positif signifikan terhadap profitabilitas perusahaan.

$\mathrm{H}_{2}$ : Ukuran perusahaan berpengaruh positif dan signifikan terhadap profitabilitas.

Likuiditas menunjukan kemampuan untuk membayar kewajiban finansial jangka pendek tepat pada waktunya, likuiditas perusahaan ditunjukan oleh besar kecilnya aktiva lancar. Current ratio atau rasio lancar adalah nilai yang menunjukkan ketersediaan aset lancar untuk memenuhi kewajiban lancar, dengan demikian semakin besar nilai CR maka semakin kecil ROA. Nilai CR yang tinggi menunjukkan bahwa perusahaan melakukan penempatan dana yang besar pada sisi aktiva lancar. Menurut penelitian yang dilakukan oleh Khatik and Veryhese (2015) likuiditas (current ratio) berpengaruh positif signifikan terhadap profitabilitas perusahaan. 
$\mathrm{H}_{3}$ : Likuiditas berpengaruh positif dan signifikan terhadap profitabilitas.

\section{METODE PENELITIAN}

Penelitian ini dilakukan pada perusahaan tekstil dan garmen di Bursa Efek Indonesia dengan menggunakan laman www.idx.co.id untuk mendapatkan informasi yang diperlukan. Ruang lingkup penelitian ini adalah perusahaan tekstil dan garmen yang tercatat aktif periode 2014-2016 yang berjumlah sebanyak 18 perusahaan.

Profitabilitas dalam penelitian ini diproksikan dengan ROA yang dapat dihitung dengan menggunakan rumus sebagai berikut. Diukur dalam satuan persentase (Kasmir, 2012:205).

ROA $=\frac{\text { Laba Bersih Setelah Pajak }}{\text { Total Aktiva }} \times 100 \%$

Perputaran modal kerja diukur dengan membandingkan antara penjualan dengan total aktiva lancar dikurangi hutang lancar. Perputaran modal kerja dirumuskan sebagai berikut (Kasmir, 2012:182).

Perputaran modal kerja $=\frac{\text { Penjualan }}{\text { Aktiva Lancar }- \text { Hutang Lancar }}$

Ukuran perusahaan dalam penelitian ini diproksikan dengan nilai logaritma dari total aktiva dalam satuan rasio atau persen. Secara sistematis ukuran perusahaan (size) dirumuskan sebagai berikut (Riyanto, 2008).

Ukuran perusahaan $($ size $)=$ LnTotalAktiva

Likuiditas dalam penelitian ini diproksikan dengan Current Ratio (CR) yang dapat diukur dengan rumus berikut. Diukur dalam satuan persentase (Sutrisno, 2001:247). 
Current ratio $=\frac{\text { Aktiva Lancar }}{\text { Hutang Lancar }} \times 100 \%$

Populasi dalam penelitian ini adalah seluruh perusahaan dalam industri tekstil dan garmen di BEI periode tahun 2014-2016 yaitu sejumlah 18 perusahaan. Metode penentuan sampel yang digunakan dalam penelitian ini adalah purposive sampling yang merupakan teknik penentuan sampel anggota populasi dengan pertimbangan atau kriteria tertentu (Sugiyono, 2008:78). Perusahaan sampel tersebut dipilih berdasarkan kriteria yaitu perusahaan industri tekstil dan garmen yang memiliki laba positif selama periode 2014-2016. Berdasarkan kriteria tersebut, sampel penelitian yang didapatkan berjumlah 8 perusahaan dengan 24 data pengamatan periode tahun 2014-2016.

Metode pengumpulan data yang digunakan dalam penelitian ini adalah metode observasi non partisipan, yaitu metode pengumpulan data dengan melakukan pengamatan namun peneliti tidak terlibat dan hanya sebagai pengamat independen (Sugiyono, 2012:204). Data dalam penelitian ini dikumpulkan dengan cara menganalisis laporan keuangan tahunan perusahaan tekstil dan garmen di BEI.

Penelitian ini menggunakan teknik analisis regresi linier berganda dalam pengolahan data, dimana teknik ini digunakan untuk mengestimasi nilai variabel dependen dengan menggunakan lebih dari satu variabel independen. Pengolahan data dikerjakan dengan bantuan Statistica Program and Service Solution (SPSS) versi 13.0 for windows. Formulasi persamaan regresi linier berganda dirumuskan sebagai berikut (Wirawan, 2002:293) :

$$
\mathrm{Y}=\alpha+\beta_{1} \mathrm{X}_{1}+\beta_{2} \mathrm{X}_{2}+\beta_{3} \mathrm{X}_{3}+\mathrm{e}
$$


Keterangan :

$\begin{array}{lrl}\mathrm{Y} & : & \text { Profitabilitas (ROA) } \\ \alpha \quad: & \text { Bilangan Konstanta } \\ \beta_{1-} \beta_{3}: & \text { Koefisien Regresi dari masing-masing variabel independen } \\ \mathrm{X}_{1}: & \text { Perputaran Modal Kerja } \\ \mathrm{X}_{2}: & \text { Ukuran Perusahaan } \\ \mathrm{X}_{3}: & \text { Likuiditas } \\ \mathrm{e} & : & \text { error }\end{array}$

\section{HASIL PENELITIAN DAN PEMBAHASAN}

Berdasarkan hasil olahan data dengan program SPSS diperoleh data statistik deskriptif yang memberikan informasi mengenai nilai minimum, nilai maksimum, rata-rata variabel penelitian dan nilai standar deviasi dari masing masing variabel. Hasil statistik deskriptif disajikan pada Tabel 1.

Tabel 1. Hasil Uji Statistik Deskriptif

\begin{tabular}{crrrrr}
\hline & N & Minimum & Maksimum & Mean & Std.Deviation \\
\hline ROA & 24 & 0,04 & 9,94 & 2,8729 & 2,98095 \\
Perputaran Modal Kerja & 24 & $-1,60$ & 941,48 & 45,2146 & 191,07798 \\
Ukuran Pers & 24 & 12,99 & 16,36 & 14,3871 & 1,30521 \\
Likuiditas & 24 & 45,03 & 532,82 & 200,8096 & 134,31782 \\
\hline
\end{tabular}

Sumber: Data diolah, 2018

Berdasarkan Tabel 1 diketahui bahwa terdapat empat variabel penelitian yaitu, profitabilitas, perputaran modal kerja, ukuran perusahaan dan likuiditas. Jumlah data pengamatan keseluruhan juga dapat dilihat pada tabel yaitu sebanyak 24 pengamatan. Penjelasan mengenai hasil perhitungan statistik deskriptif diuraikan bahwa profitabilitas dalam penelitian ini diproksikan dengan return on asset (ROA). Berdasarkan hasil statistik deskriptif yang ditunjukkan pada Tabel 1 dengan jumlah data $(\mathrm{N})$ sebanyak 24 dengan periode waktu tiga tahun (20142016) menunjukkan nilai rata-rata (mean) 2,87259 dengan standar deviasi sebesar 
2,98095. Nilai terendah (minimum) dari profitabilitas (ROA) 0,04 dimiliki oleh Star Petrochem Tbk ditahun 2014 dan 2015, sedangkan nilai tertinggi (maksimum) dari profitabilitas (ROA) adalah 9,94 dimiliki oleh Eratek Djaja Tbk ditahun 2015.

Berdasarkan hasil statistik deskriptif yang ditunjukkan pada Tabel 1. dengan jumlah data $(\mathrm{N})$ sebanyak 24 dengan periode waktu tiga tahun (2014-2016) menunjukkan nilai rata-rata (mean) perputaran modal kerja sebesar 45,2146 dengan standar deviasi sebesar 191,07798. Nilai terendah (minimum) dari perputaran modal kerja $-1,60$ dimiliki oleh Nusantara Inti Corpora Tbk ditahun 2016, sedangkan nilai tertinggi (maksimum) dari perputaran modal kerja adalah dimiliki 941,48 oleh Eratek Djaja Tbk ditahun 2014.

Berdasarkan hasil statistik deskriptif yang ditunjukkan pada Tabel 1 dengan jumlah data $(\mathrm{N})$ sebanyak 24 dengan periode waktu tiga tahun (20142016) menunjukkan nilai rata-rata (mean) ukuran perusahaan sebesar 14,3871 dengan standar deviasi sebesar 1,30521. Nilai terendah (minimum) 12,99 dari ukuran perusahaan dimiliki oleh Nusantara Inti Corpora Tbk ditahun 2016, sedangkan nilai tertinggi (maksimum) dari ukuran perusahaan adalah 16,36 dimiliki oleh Sri Rejeki Isma Tbk ditahun 2016.

Likuiditas dalam penelitian ini diproksikan dengan current ratio (CR). Berdasarkan hasil statistik deskriptif yang ditunjukkan pada Tabel 1 dengan jumlah data $(\mathrm{N})$ sebanyak 24 dengan periode waktu tiga tahun (2014-2016) menunjukkan nilai rata-rata (mean) 200,8096 dengan standar deviasi sebesar 134,31782. Nilai terendah (minimum) dari likuiditas 45,03 dimiliki oleh 
Nusantara Inti Corpora Tbk ditahun 2014, sedangkan nilai tertinggi (maksimum) dari likuiditas adalah 532,82 dimiliki oleh Sri Rejeki Isma Tbk ditahun 2014.

Analisis regresi linier berganda digunakan untuk mengetahui arah dan besarnya pengaruh perputaran modal kerja, ukuran perusahaan dan likuiditas terhadap profitabilitas perusahaan tekstil dan garmen yang terdaftar di Bursa Efek Indonesia. Untuk mempermudah pengolahan data digunakan program SPSS. Hasil analisis regresi linear berganda disajikan pada Tabel 2.

Tabel 2.

Hasil Uji Analisis Regresi Linier Berganda

\begin{tabular}{|c|c|c|c|c|c|}
\hline \multirow[t]{2}{*}{ Model } & \multicolumn{2}{|c|}{$\begin{array}{c}\text { Unstandardized } \\
\text { Coefficients }\end{array}$} & \multirow{2}{*}{$\begin{array}{c}\text { Standardized } \\
\text { Coefficients } \\
\text { Beta }\end{array}$} & \multirow[t]{2}{*}{$\mathbf{T}$} & \multirow[t]{2}{*}{ Sig } \\
\hline & B & Std.Error & & & \\
\hline 1 (Constant) & 7,124 & 7,235 & & 1,985 & 0,337 \\
\hline $\mathrm{X}_{1}$ & 0,296 & 0,103 & 0,383 & 2,872 & 0,017 \\
\hline $\mathrm{X}_{2}$ & 0,188 & 0,073 & 0,342 & 2,606 & 0,192 \\
\hline $\mathrm{X}_{3}$ & 0,259 & 0,109 & 0,276 & 2,378 & 0,023 \\
\hline
\end{tabular}

Sumber: Data diolah, 2018

Berdasarkan Tabel 2 diatas dapat dirumuskan persamaan regresi linier berganda sebagai berikut :

$\mathrm{Y}=7,124+0,296\left(\mathrm{X}_{1}\right)+0,188\left(\mathrm{X}_{2}\right)+0,259\left(\mathrm{X}_{3}\right)$

Keterangan :

$\mathrm{Y}=$ Profitabilitas

$\mathrm{X}_{1}=$ Perputaran Modal Kerja

$\mathrm{X}_{2}=$ Ukuran Perusahaan

$\mathrm{X}_{3}=$ Likuiditas

Hasil penelitian ini menunjukkan bahwa perputaran modal kerja berpengaruh positif dan signifikan terhadap profitabilitas yang diproksikan dengan ROA pada perusahaan tekstil dan garmen di BEI periode 2014-2016. Jadi hasil penelitian ini mendukung hipotesis yang pertama yaitu perputaran modal kerja berpengaruh 
positif dan signifikan terhadap profitabilitas perusahaan tekstil dan garmen di BEI periode 2014-2016. Semakin tinggi tingkat perputaran modal kerja semakin efektif penggunaan modal kerja dan semakin cepat modal kerja berputar semakin besar keuntungan yang didapatkan untuk meningkatkan profitabilitas perusahaan. Hasil penelitian ini didukung oleh hasil penelitian sebelumnya yang dilakukan oleh Adjapong and Padachi (2014), Geetam and Samanta (2017), Tsagem et al. (2015) sertaDharmendra (2015) yang mendapatkan hasil bahwa perputaran modal kerja berpengaruh positif dan signifikan terhadap profitabilitas perusahaan.

Hasil penelitian ini menunjukkan bahwa ukuran perusahaan positif dan tidak berpengaruh signifikan terhadap profitabilitas yang diproksikan dengan ROA pada perusahaan tekstil dan garmen di BEI periode 2014-2016. Berdasarkan temuan dalam penelitian ini, maka hipotesis kedua ditolak. Hasil penelitian ini didukung oleh penelitian yang dilakukan oleh (Sari dan Budiasih, 2014). Ukuran perusahaan menggambarkan besar kecilnya suatu perusahaan. Penentuan besar kecilnya skala perusahaan dapat ditentukan berdasarkan total penjualan, rata-rata tingkat penjualan, total aktiva dan rata-rata total aktiva. Perusahaan yang besar memiliki total asset yang besar, sehingga perusahaan mampu mengoptimalkan kinerja perusahaan, dengan aset yang dimilikinya. Namun dalam penelitian ini ditemukan bahwa besar kecilnya aset tidak berpengaruh terhadap profitabilitas. Pengaruh yang tidak signifikan ini diakibatkan oleh semakin besar ukuran suatu perusahaan, maka perusahaan tersebut akan membutuhkan biaya yang semakin besar untuk menjalankan aktivitas operasionalnya seperti biaya tenaga kerja, biaya administrasi dan umum serta biaya pemeliharaan gedung, mesin, kendaraan dan 
peralatan sehingga akan mampu mengurangi profitabilitas perusahaan (Sari dan Budiasih, 2014). Optimalisasi dalam pengelolaan aset juga memiliki peran pada kemajuan perusahaan menghasilkan profit. Hasil penelitian ini tidak sejalan dengan penelitian yang dilakukan oleh Yazdanfar and Ohman (2014), Ehi-Oshio et al. (2013), Gill et al.(2011), Abu Tapanjeh (2016), Yazdanfar Darush (2013) serta Niresh and Velnampy (2014) yang menunjukkan bahwa ukuran perusahaan berpengaruh positif signifikan terhadap profitabilitas perusahaan.

Hasil penelitian ini menunjukkan bahwa likuiditas yang diproksikan dengan $\mathrm{CR}$ berpengaruh positif dan signifikan terhadap profitabilitas yang diproksikan dengan ROA pada perusahaan tekstil dan garmen di BEI periode 2014-2016.Jadi hasil penelitian ini mendukung hipotesis yang ketiga yaitu likuiditas berpengaruh positif dan signifikan terhadap profitabilitas perusahaan tekstil dan garmen di BEI periode 2014-2016. Semakin tinggi current ratio berarti semakin besar kemampuan perusahaan untuk memenuhi kewajiban jangka pendek. Nilai current ratio yang tinggi menunjukkan bahwa perusahaan melakukan penempatan dana yang besar pada sisi aktiva lancar. Jadi hal ini tidak baik bagi profitabilitas perusahaan karena aktiva lancar menghasilkan return yang lebih rendah dibandingkan dengan aktiva tetap. Hasil penelitian ini didukung oleh hasil penelitian sebelumnya yang dilakukan oleh Khatik and Veryhese (2015) likuiditas (current ratio) berpengaruh positif dan signifikan terhadap profitabilitas perusahaan.

Koefisiean determinasi berfungsi untuk melihat sejauh mana seluruh variabel independen dapat dijelaskan variabel dependen. Apabila angka koefisien 
determinasi mendekati 1 , maka pengujian variabel independen terhadap variabel dependen adalah semakin kuat, yang berarti bahwa variabel-variabel independen memberikan hampir semua informasi yang dibutuhkan untuk memprediksi variasi variabel dependen.Hasil Uji Determinasi disajikan pada Tabel 3.

Tabel 3.

Hasil Uji Determinasi

\begin{tabular}{lcccc}
\hline Model & R & R Square & $\begin{array}{c}\text { Adjusted R } \\
\text { Square }\end{array}$ & $\begin{array}{c}\text { Std. Error of } \\
\text { the Estimate }\end{array}$ \\
\hline $1 \quad 0,783^{\text {a }}$ & 0,613 & 0,554 & 1,121 \\
\hline \multicolumn{2}{r}{ Sumber: Data diolah, 2018} & & &
\end{tabular}

Berdasarkan Tabel 3 diatas dapat dilihat nilai dari R Square adalah sebesar 0, 613 yang artinya sebesar 61,3 persen variasi ROA dipengaruhi oleh perputaran modal kerja, ukuran perusahaan, dan likuiditas, sedangkan sisanya sebesar 38,7 persen dipengaruhi oleh faktor-faktor lain yang tidak dimasukkan ke dalam model penelitian.

Penelitian ini membahas mengenai pengaruh variabel perputaran modal kerja, ukuran perusahaan dan likuiditas terhadap profitabilitas pada perusahaan tekstil dan garmen di BEI periode 2014-2016. Implikasi dari penelitian ini yaitu pertama variabel perputaran modal kerja, dari hasil penelitian ditemukan bahwa variabel ini memiliki pengaruh positif signifikan terhadap profitabilitas atau ROA pada perusahaan tekstil dan garmen. Modal kerja adalah salah satu hal yang sangat penting bagi perusahaan karena perusahaan selalu membutuhkan modal kerja agar dapat membiayai kegiatan perusahaannya sehari-hari dimana dana yang sudah dikeluarkan diharapkan bisa cepat kembali lagi masuk kedalam kas perusahaan melalui hasil penjualannya. Adanya modal kerja yang berlebihan 
menunjukkan adanya dana yang tidak produktif dan hal ini memberikan kerugian karena dana yang tersedia tidak digunakan untuk kegiatan perusahaan. Sebaliknya, kekurangan modal kerja merupakan sebab utama kegagalan perusahaan dalan menjalankan perusahaannya. Jadi modal kerja yang baik dan cukup akan menunjang tingginya profitabilitas perusahaan, semakin tinggi tingkat perputaran modal kerja semakin efektif penggunaan modal kerja dan semakin cepat modal kerja berputar semakin besar keuntungan yang didapatkan untuk meningkatkan profitabilitas perusahaan.

Variabel kedua adalah ukuran perusahaan, dari hasil penelitian ditemukan bahwa variabel ini tidak memiliki pengaruh signifikan terhadap profitabilitas atau ROA pada perusahaan tekstil dan garmen. Ukuran perusahaan menggambarkan besar kecilnya suatu perusahaan. Penentuan besar kecilnya skala perusahaan dapat ditentukan berdasarkan total penjualan, rata-rata tingkat penjualan, total aktiva dan rata-rata total aktiva. Pada penelitian ini ditemukan bahwa perusahaan besar tidak selalu memiliki tingkat profitabilitas yang tinggi. Perusahaan dengan ukuran yang lebih kecil juga mampu menghasilkan profitabilitas yang tinggi. Optimalisasi penggunaan aset berperan penting dalam kemampuan perusahaan menghasilkan profit. Pengaruh yang tidak signifikan ini diakibatkan oleh semakin besar ukuran suatu perusahaan, maka perusahaan tersebut akan membutuhkan biaya yang semakin besar untuk menjalankan aktivitas operasionalnya.

Variabel ketiga adalah Likuiditas yang diproksikan dengan CR, dari hasil penelitian ditemukan bahwa variabel ini memiliki pengaruh positif signifikan terhadap profitabilitas atau ROA pada perusahaan tekstil dan garmen. Likuiditas 
menunjukan kemampuan untuk membayar kewajiban finansial jangka pendek tepat pada waktunya, likuiditas perusahaan ditunjukan oleh besar kecilnya aktiva lancar. Current ratio atau rasio lancar adalah nilai yang menunjukkan ketersediaan aset lancar untuk memenuhi kewajiban lancar, dengan demikian semakin besar nilai $\mathrm{CR}$ maka semakin besar ROA. Nilai CR yang tinggi menunjukkan bahwa perusahaan melakukan penempatan dana yang besar pada sisi aktiva lancar.

\section{SIMPULAN DAN SARAN}

Berdasarkan hasil pembahasan yang telah diuraikan sebelumnya, maka diperoleh simpulan bahwa perputaran modal kerja berpengaruh positif signifikan terhadap profitabilitas pada perusahaan tekstil dan garmen yang terdaftar di Bursa Efek Indonesia periode 2014-2016. Ukuran perusahaan tidak berpengaruh signifikan terhadap profitabilitas pada perusahaan tekstil dan garmen yang terdaftar di Bursa Efek Indonesia periode 2014-2016. Likuiditas berpengaruh positif signifikan terhadap profitabilitas pada perusahaan tekstil dan garmen yang terdaftar di Bursa Efek Indonesia periode 2014-2016.

Berdasarkan simpulan dan analisis yang telah dilakukan, maka saran yang dapat dikemukakan bagi pihak perusahaan adalah pada pihak perusahaan sebaiknya mengoptimalkan dan meningkatkan perputaran modal kerja dan likuiditas yang diproksikan dengan $\mathrm{CR}$, karena variabel ini memiliki hubungan yang positif terhadap profitabilitas (ROA). Hal ini berarti pihak perusahaan harus memperhatikan variabel-variabel yang memiliki hubungan positif terhadap profitabilitas. Sedangkan ukuran perusahaan tidak berpengaruh terhadap 
profitabilitas ini berarti perusahaan besar belum tentu memiliki profitabilitas yang lebih baik dari perusahaan dengan ukuran yang lebih kecil. Bagi peneliti selanjutnya disarankan agar tidak hanya memakai variabel perputaran modal kerja, ukuran perusahaan dan likuiditas untuk menganalisis pengaruhnya terhadap profitabilitas. Hal ini dikarenakan masih ada faktor-faktor lain yang dapat mempengaruhi profitabilitas perusahaan. Selain itu peneliti selanjutnya disarankan untuk menambah tahun pengamatan dengan harapan akan memperoleh hasil yang lebih baik lagi sehingga hasil yang diperoleh dapat dijadikan dasar pengambilan keputusan bagi pihak-pihak yang membutuhkan.

\section{REFERENSI}

Abu Tapanjeh M A. 2016. An Empirical Study of Firm Stucture and Profitability Relationship The Case of Jordan. Journal of Economic and Administrative Sciences, Vol. 22, No. 1, pp. 41-59.

Adjapong G and Padachi K, Received. 2014. Working Capital Level Influence on SME Profitability. Journal of Small Business and Enterprise Development, Vol. 23, No. 1, pp. 44-63.

Brigham, Eugene F dan Joul F Huston. 2012. Dasar-Dasar Manajemen Keuangan. Jakarta: Salemba Empat.

Bursa Efek Indonesia. Laporan Keuangan \& Tahunan. www.idx.co.id

Dharmendra S. 2015. Working Capital Management and Profitability A Case Study of Automobile Industry in India. Bi-annual Journal of Asian School of Bussiness Management, Vol. 3, No. 2, pp. 1-7.

Ehi-Oshio. O.U, Adeyemi A and Augustine O. Enofe. Dr . 2013. Determinants of Corporate Profitability in Developing Economies. European Journal of Business and Management, Vol. 5, No. 16, pp. 42-50.

Esra, Martha Ayerza dan Prima Apriweni. 2005. Manajemen Modal Kerja. Jurnal Ekonomi Perusahaan. STIE iBii, Vol. 12, No. 1, Hal. 99-222 
Geetam S and Samanta P K. 2017. Working Capital Management and Profitability: An Empirical Analysis of Infrastructure Companies. ASBM Journal of Management, Vol. 10, No. 11, pp. 29-39.

Gill, Amarjit and Mathur, Neil. 2011. The Impact of Board Size, CEO Duality, and Corporate Liquidity on the Profitability of Canadian Service Firm. Journal of Applied Finance and Banking, Vol. 1, No. 3, pp. 83-95

Hanafi, Mamduh dan Halim, Abdul. 2003. Analisis Laporan Keuangan. Edisi Revisi. Yogyakarta: UPP AMP YKPN.

Kasmir. 2010. Pengantar Manajemen Keuangan. Jakarta: Predana Media.

Kasmir. 2013. Analisis Laporan Keuangan. Jakarta : Rajawali. Pers

Khatik and Varghese T. 2015. Impact of Working Capital Management on Firm Profitability: An Empirical Study of ITC Ltd. International Journal of Information Business and Management, Vol. 7, No. 4, pp. 284-305.

Lukman Syamsudin. 2007. Manajemen Keuangan Perusahaan. Jakarta: Raja Grafindo Persada.

Munawir. 2012. Analisis Informasi Keuangan. Yogyakarta: Liberty.

Niresh J A and Velnampy T. 2014. Firm Size and Profitability: A Study of Listed Manufacturing Firm in Sri Lanka. International Journal of Business and Management, Vol. 9, No. 4, pp. 57-64

Putra, Lutfi Jaya. 2012. Pengaruh Perputaran Modal Kerja Terhadap Profitabilitas (Studi Kasus: PT Indofood Sukses Makmur Tbk). Jurnal Ekonomi Gunadarma, Vol. 9, No. 1, pp. 1-10.

Raharjaputra, H.S. 2009. Manajemen Keuangan dan Akuntansi. Jakarta: Salemba Empat Reeve, James M. 2010. Pengantar Akuntansi (Adaptasi Indonesia. Jakarta: Salemba Empat.

Ramadan, Zeyad S. 2012. Does Leverage Always Mean Risk? Evidance from ASE. International Journal of Economics and Finance, Vol. 4, No. 12, pp. $150-158$.

Riyanto, Bambang. 2011. Dasar-Dasar Pembelanjaan Perusahaan. Yogyakarta: BPEF.

Samsul, Mohamad. 2006. Pasar Modal \& Manajemen Portofolio. Jakarta: Erlangga. 
Sari, Vironika dan Budiasih. 2014. Pengaruh Debt To Equity Ratio, Firm Size, Inventory Turnover dan Assets Turnover Pada Profitabilitas". E-Jurnal Akuntansi Universitas Udayana. Edisi 2014 hal. 261-273.

Sartono, Agus. 2010. Manajemen Keuangan Teori dan Aplikasi. Edisi Empat. Yogyakarta: BPFE.

Sartono, Agus. 2011. Manajemen Keuangan Teori dan Aplikasi. Yogyakarta: BPFE.

Sawir, Agnes. 2005. Analisis Kinerja Keuangan dan Perencanaan Keuangan Perusahaan. Jakarta: PT Gramedia Pustaka.

Sawir, Agnes. 2009. Analisa Kinerja Keuangan dan Perencanaan Keuangan Perusahaan. Jakarta: PT Gramedia Pustaka Utama.

Seftianne dan Handayani. 2011. Faktor-Faktor yang Mempengaruhi Struktur Modal pada Perusahaan Publik Sektor Manufaktur. Jurnal Bisnis dan Akuntansi, Vol. 13, No. 1, pp. 39-56.

Soebiantoro, U. 2007. Pengaruh Struktur Kepemilikan Saham, Leverage, Faktor Intern Dan Faktor Ekstern Terhadap Nilai Perusahaan. Jurnal Manajemen dan Kewirausahaan, Vol.9, No.1, hal. 41-48.

Sugiyono. 2012. Metode Penelitian Kuantitatif, Kualitatif, dan R\&D. Bandung: Alfabeta.

Sutrisno. 2001. Manajemen Keuangan Teori, Konsep, dan Aplikasi. Yogyakarta : Ekonosia.

Tandelilin. 2010. Portofolio dan Investasi. Yogyakarta: Kanisius.

Tsagem, M. M., Aripin Norhani and Ishak Rokiah . 2015. Impact of Working Capital Management Ownership Structure and Board Size on the Profitability of Small and Medium Sized Entities in Nigeria. International Journal of Economics and Financial Issues, Vol. 5, pp. 77-83.

Tsagem, M. M., Aripin Norhani and Ishak Rokiah. 2017. Impact of Working Capital Management on Firm Profitability: Evidance from Scandinavian Countries. Journal of Business Strategies, Vol. 11, No.1, pp. 99-112

Varghese T and Dhote K K. 2014. Impact of Capital Management on Firm Profitability: A Case Study of HUL Ltd India. International Journal of Financial Management, Vol. 4, No. 4, pp. 57-66

Wirawan, Nata. 2002. Cara Mudah Memahami Statistika 2. Denpasar : Keraras Emas. 
Yazdanfar D and Ohman P. 2014. The Impact of Cash Conversion Cycle on Firm Profitability An Empirical Study Based On Swedish. International Journal of Management Finance, Vol. 10, No. 4, pp. 442-452.

Yazdanfar D and Ohman P. 2016. The Impact of Trade Credit Use on Firm Profitability: Empirical Evidence from Swedan. Journal of Advances in Management Research, Vol. 13, No. 2, pp. 116-129.

Yazdanfar Darush. 2013. Profitability Determinants Among Micro Firm Evidence from Swedish Data. International Journal of Managerial Financ, Vol. 9, No. 2, pp. 150-160.

Zeeshan. A, Awan, M. Z, Safdar, M. Z, Hasnain. T, Kamran. M. 2016. A Nexus Between Working Capital Management and Profitability: A Case Study of Pharmaceutical Sector in Pakistan. International Journal of Economics and Financial Issues, Vol. 6, pp. 153-160.

http://www.tribunnews.com/bisnis/2018/04/05/tekstil-dan-garmen-jadi-industristrategis-di-indonesia (diakses tgl 6 juni 2018 pukul 20.00 WITA). 